\title{
The Similarities and Differences between the Spring Festival in China and Christmas in America
}

\author{
Lina Zhao \\ Xi’an Peihua University, Xi’an, China
}

Keywords: the Spring Festival, Christmas, Similarities, Differences

\begin{abstract}
Festivals granted with special meanings of the social culture not only are the embodiment of people's colourful life, but also the generalization and the extension of each country's economy, polities, culture as well as religion. Traditional festivals are the complicated phenomenon of social culture, which conclude character, belief, conception, the way of thinking, morality and aesthetic habits that are formed and deposited in its long history river. Nowadays, with the development of the technology and economy, the connections between different countries have becoming more and more tight and a vast majority of people start to realize the importance of learning English , but they ignore the significance of the different culture in different countries, which is pretty improper and conflicts are easy to occur. Therefore, festivals are the easy access for us to learn the foreign custom and culture as the indispensable part of the culture. By the means of comparison and contrast of these two countries' important festivals in the Spring Festival and the Christmas, it's conductive to absorb American civilization rationally, to protect our national culture's quintessence as well as to promote intercultural communication.
\end{abstract}

\section{Introduction}

Nowadays, with the development of technology and economy, people's life has changed greatly, which can be seen from the way people celebrate the festivals. In the past, people only celebrate their own national festivals. Now, people not only care about their national festivals, but also foreign festivals. This is why people realize that festivals, as the product of the history, are the shortcut to get a general idea of a country. Hence, it's necessary for us to learn the foreign culture and absorb the essence of the culture to make our culture more diverse and attractive.

In this paper, firstly, I will discuss some author's opinion about the Spring Festival and the Christmas. Then I will introduce the origin and the customs of the respective festivals. In the Chapter four, some similarities of the two festivals will be shown. At last, according to the difference and the similarities of these two festivals, people have a better understanding of China and America.

\section{Literature Review}

China has seven traditional festivals. The Spring Festival has the largest influence on Chinese among all the festivals. In every Spring Festival, people try to go back to their hometown, no matter where they are, just for being with their families. They will cook ravioli, and celebrate the New Year together. Christmas in America is also the biggest celebration. People go to the church for praying, have a Christmas tree, and send gift cards to each other. The environment in the festival is peaceful. People have so many good wishes to the future.

\section{Commercialized festival}

In this article, I will discuss some authors' ideas. Firstly, as we all know the festival has been commercialized more or less, so have the festivals lost the connotation? Secondly, does the Spring Festival have the same position as Christmas? Thirdly, what kind of influence has the festival made on the society? What's more, what can we learn behind the festival? Lastly, why do America people 
worship the God when Chinese people reverent the ancestors? What's the reason?

The author, Sherry Bonnice, believes that "although many people complain that Christmas has become commercialized to the point where it has lost its meaning, the Christmas continues to shine with a light that is deeper than marketing and Christmas sales. Across North America, Christmas is an occasion for love and joy, a time to reach out to others, and a time to celebrate."

I agree with the author. In North America, since the 20th century, Santa Claus became the symbol for the spirit of generosity. In the early 1900s, people were focusing on children in a new way: the needs of prohibited child labour. Out of this movement came the concept that every child had the right to a happy Christmas-and Santa Claus was the symbol of this universal need. His image appeared everywhere-on greeting cards, in magazines, and in cartoons. Men dressed as Santa began to stand on streets corners, ringing bells and collecting money for charities. Today, filling the Salvation Army kettles is still one of the mall kettles offer the young and old the opportunity to give those in need. Donations still reach children, both in North America and in poverty-stricken countries around the world. Contributions also benefit AIDS research and contribute to homeless shelters across North America.

We cannot deny that with the development of the global economy, the festival has been commercialized to some extent. However, just like the Spring Festival, although businessmen would make full advantage of the festival through the promotion of exquisite gift, decorated food and so on, Our Chinese people still protect and promote the essence of cultural values, as well as follow the traditional customs.

What's more, in my opinion, we should treat commercialization rationally. Every coin has its two sides. On one hand, we cannot deny with the development of the global economy, the festival has been commercialized, which, to some extent, contributes to the loss of the traditional value of the festival. On the other hand, commercialization serves as the bridge of cultural exchange. What's more, should we be grateful to the development of the global economics that let us find an excuse of evading the hectic world and exposing ourselves to the enthusiastic festival atmosphere created by the businessmen?

Christmas is regarded as the most important holiday in America, though more or less influenced by its times, it still embodies and transmits the cultural implications of the festival. Therefore, the Spring Festival and the Christmas, as the representatives of respective nation's culture, are the typical examples to explore the cultural differences between Chinese and America festivals.

\section{The hot of Christmas}

The author, Lin Xi, believes that the Spring Festival will not be replaced by the Christmas. I agree with the author. Shi Ying, the head of Institutes Sociology and a researcher at Academy of Social Scientists in Shanxi province said that the reason why the atmosphere of the Christmas is increasingly becoming hot is that businessmen cater to the idea-seeking for novelty and changes of the youth, but this is just an excuse for young people to play outside with their friends, and what's more the Spring Festival itself has the powerful vitality, so there is no need to worry excessively on this issue. What's more, a foreign friend said that in America, people enjoy the Christmas with their families, just like the Spring Festival. She believes that since the implementation of the reform and opening-up policy, a vast majority of young people are interested about the novel, fashionable things. They rarely know about the meaning of the Christmas, but they just want to make full use of this festival to play with their friends.

Just think about the growing passenger traffic demand during the Spring Festival, which makes the stations some kind of the phenomenon. As a matter of fact, the Spring Festival and the Christmas have the equal position in their respective countries. In their own countries, people would enjoy their festivals with their families. Furthermore, although the way people celebrate the festival may change, the connotation of the festival remains the same.

Nowadays, as people becoming more open-minded, the Spring Festival has been spread into other countries and it's well accepted by foreigners. As we can see, during the Spring Festival, people in Los. Angles would celebrate it like Chinese people do. In fact, with the access to the 
western festivals, our own country's festival would not disappear, but on the contrary, it would enrich our own country's festivals and let us understand other countries' culture so as to avoid the cultural shock.

Nowadays, with the rapid development of the technology and economy, it's necessary for us to acquaint ourselves with other countries' culture and always keep a reasonable, positive, tolerant attitude toward them.

\section{Big sales of the festivals}

The author, Zhang Haixia, believes that both the Spring Festival and the Christmas are the prime time for promotion. I agree with the author. Around the Spring Festival, the shopping desire of people will be stimulated greatly. The sales volume of the shopping mall, in clothing, food, gifts and so on, will go through the roof.

Because people work hard in the whole year, they are willing to seize the opportunity to enjoy the Spring Festival with their friends and families, with large amount of food available or have a trip to relax themselves, which are as same as people do in America at Christmas. What's more, people tend to buy the things under the impulse of the trend.

Nowadays, we should attach significant importance to the grand festivals, not only look into the connotation of the festival, but also see through how people view the festivals, which can give us insight into better comprehension of the festival. What's more, we can also make full advantage of the festival to promote the economy.

\section{Different values}

The authors, Dang Linning, Gao Juxia, by the means of comparison the two festivals origins and customs, find the Chinese interpersonal relationship is characterized of group orientation, kinship, and feelings emphasized, while the American are individualism orientation, freedom and equality emphasized. Furthermore, Chinese are more implicit than American.

I agree with the authors. Our traditional Chinese festivals' activities are family-oriented. In the Spring Festival, young people have to visit the older first and family members, near or far, have to get together to celebrate the festivals. What's more, people need to visit their relatives, sending the auspicious words or phrases, such as "Happy New Year". While in America, it's on the opposite way. Americans are more people-oriented. American festivals display more about people's participation, interactivity, carnival-orientation and self-assertion. They don't have the bond of upper-lower relationship, the age-youth relationship and so on. On the contrary, they are equal and free. It's quite common that people in America would celebrate with a group of strangers, which is inconceivable in China.

With regard to the expression of people's feelings, Chinese people are more reserved. For example, when Chinese people received the gifts, they usually refused to accept the gifts at first, and after a lot of persuasion of the giver, they will finally accept the gifts. Afterwards, they will not open the gifts in front of giver unless the giver leaves. As to American people, they are more straight faced this case. They will directly open the gifts in front of the giver and then express their gratitude and excitement.

Without understanding of the difference, people may get confused and misunderstand each other feeling. What's more, with the development of the economy, cross-cultural communication becomes more and more frequent. Therefore, we cannot afford to ignore the festival culture. The traditional festivals both in China and America are the indispensable part of their own culture, and they influence people's daily life. It's necessary for us to study the connotation of the festival as well as the reflection of the Sino-American difference in expression of their feelings, values and beliefs, which can help us to understand American people and avoid conflict. 


\section{Different beliefs}

The authors, Luo Xiaoli, Xiao Lizhen, believe that American people pay more attention to the worship of the God, while Chinese people lay emphasis on the reverence for ancestors. This difference is caused by their profound culture.

I agree with the author. Since Han Dynasty, people would emphasize filial piety. Fete progenitor took an important position in the worship activity and the culture of filial piety. During the Spring Festival, people would visit the graves of their ancestor. Usually, people would clean the tombs, offer the food, alcohol and trinkets, as well as set off firecrackers to express the meaning that ancestors would be with the people alive to celebrate the New Year together. While in America, people mainly express their gratitude and reverence of the God and the son of God, Jesus in the period of the Christmas. Take singing as an example, there are many songs, such as Joy to the World, Angels We Have Heard on High, Away in the Manger and so on, all of which are honoring Christ's birth and celebrating good will, peace, as well as hope among all people.

The reasons of this difference are closely related to the geographical environment, the way of the lifestyle, social system and the ideology. Firstly, the meaning granted upon the festival makes the difference. Christ's Mass is abbreviated to Christmas. Now it's widely regarded that Christmas is established to commemorate the birth of the Christ. While in China, the original meaning of the Spring Festival is to celebrate the harvest. During the Spring Festival, people will be with their families, "inviting their ancestors" to welcome the advent of the Lunar New Year.

Secondly, with the development of the society, American people more believe in the power of the God. As we all know, western culture is originated from the Greek mythology culture and the Hebrew religion culture. No matter in which culture, people are made by the God. By contrast, in China, people are made by a Goddess, NuWa, while NuWa is a human. Because of her great contribution to human beings, then she was deified. Therefore, people in America will praise the great God at Christmas, while in China, people will be grateful toward the ancestors.

Thirdly, farming culture in China makes people realize that no pains, no gains. If you want to reap, you need to sow. Life is stable. People are inclined to believe their own opinions. In America, marine culture let people do their business across the ocean, which adds to a lot of unexpected disasters that are uncontrollable. All of these uncontrollable factors make people have a deeper reverence toward the God.

Through the comparison of the differences, we can understand the root of the festival. We can know the reason why American people worship the God, while Chinese revere the ancestors; why people celebrate the festival in different way; what the origin of the festival is; how the festival influence people's life; and what we can learn from the festival.

\section{Conclusion}

Festival culture is a cultural phenomenon, which can reflect the characteristics, the belief, the thinking mode and the value of a nation. Traditional festivals are an indispensable part of festival culture. It's a treasure accumulated through the history and culture of a nation. Along the development of the global economy, inter-culture communication is tending to be more and more important. In the past, people consider they can communicate fluently only by studying foreign language. However, this is not a correct idea. Communication is also related to different cultural background and various values. It's quite necessary for us to understand the variation in China and American festival cultures and to improve the ability of cross-culture communication.

\section{References}

[1] Gareis, E. (2012). Intercultural friendship: Effects of home and host region. Journal of International and Intercultural Communication.

[2] Seiler, Robert M. "Human Communication in the British Cultural Studies Tradition." http://people.ucalgary.ca/ rseiler/british.htm 
[3] Bennett, Andy \&Keith Kahn-Harris, eds . After Subculture: Critical Studies in Contemporary Youth Culture. Houndmills, Basingstoke, Hampshire, New York: Palgrave Macmillan, 2004.
[4]
Baldwin,
$\mathrm{J}$.
R.
(2011).
Cross-cultural
adaptation.

http://my.ilstu.edu/ jrbaldw/372/Adaptation.htm

[5] Gallagher, H. C. (2012). Willingness to communicate and cross-cultural adaptation: L2 communication and acculturative stress as transaction. Applied Linguistics.

[6] Hendrickson, B., Rosen, D., \& Aune, R. K. (2011). An analysis of friendship networks, social connectedness, homesickness, and satisfaction levels of international students. International Journal of Intercultural Relations 